\title{
乳糖を基剤とした噴霧乾燥複合粒子の設計と その製剂学的応用に関する研究
}

\author{
保地 毅彦 \\ Takehiko Yasuji
}

\section{1. 研究を始めた動機}

ハイスループットスクリーニング (HTS) 等の技術 導入により，医薬品開発の川上である「創薬」の開発 スピードが高速化している現代では，その川下にある 「創剂」に拉いても製剂開発の効率化が求められてい る。医薬品製剂の開発で重要な役割を果たす添加剂に おいても，製剂操作の効率化や機能化を満たす新しい 添加剂の開発が望まれている。化学的手法による新規 添加剂の開発には医薬品開発と同等の費用と年月が必 要であるため, 粒子設計法等の物理的手法による機能 性基剂の開発が注目されている。そこで本研究では,

医薬品賦形剂として最も汎用されている乳糖を基剂と して，ゲル形成機能を有した水溶性高分子との複合粒 子化を噴霧乾燥法を用いて行い, 直接打錠能と薬物徐 放化能の両者を併せ持つ機能性基剂の開発を行った。

\section{2. 研究遂行上感じたこと}

研究室配属の際に，恩師川島嘉明教授の製剤学教室 を希望した理由の一つには，微粒子製剤（ナノスフェ ア一等）を用いて，実用化し難い化合物を医薬品にす る先端の製剤技術に興味を抱いたためであった。正直 に言って, 機能性基剂のテーマを頂いた当初は, 微粒 子担体の研究を行う先輩・同級生を羡ましく思えた が，研究年数を重称て行くに従い，「粉体」の魅力に 取りつかれ，曲がりなりにも古くて新しい粉体加工技

2001 年 4 月 12 日受付

山之内製薬(株)創剂研究所

（テ425-0072 静岡県焼津市大住180番地）TEL 054-627-5155

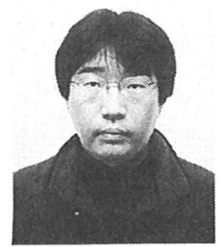

<著者紹介>

1994年 3 月岐阜薬科大学製造薬学科卒業, 1996年 3 月岐皁薬科大学大学院博士前期課程 修了, 1999 年 3 月岐阜薬科大学大学院博士後 期課程修了, 同年 4 月山之内製薬株式会社創 剂研究所, 現在に至る。薬学博士 専門; 製剂学, 粉体工学
術の一端に触れさせて頂いたことが，今後の研究人生 の大きな糧になると感じた。

研究を遂行する過程では，学位論文を仕上げる際に 必要な深さと広さを持つために, 多くの壁に遭遇し た。今振り返ると, 一つ一つの壁を乗り越える際の卜 リガーとなったものは，優れた文献に出会うことと， 日常に行う先生・研究生・先輩・後輩とのディスカッ ションにあったと思われる。月並みではあるが, 文献 や議論を切っ掛けとして自身の研究を客観的に眺め, 幅広い分野の知識と技術を持って, 研究内容の本質を 見極める力を養う重要性を痛感した。

\section{3. 主な研究成果}

本研究の内容は, 噴霧乾燥複合粒子の設計と評洒, 及び本複合粒子を用いた放出時間制御型錠剂の設計に 分けられる。以下にそれぞれの主要な成果を示す。

\section{1 噴霧乾燥複合粒子の設計之評価}

乳糖とゲル形成水溶性高分子であるアルギン酸ナ トリウム (NaAlg) の混合溶液を噴霧乾燥し, 複合粒 子 (Spray-dried composite particles : SDCoP) を 調製した。調製した SDCoP は球形度が高く，その粒 子径（平均粒子径：約 $15 \mu \mathrm{m}$ ) が一般に流動性が低下 する臨界粒子径（50～100 $\mu \mathrm{m} ）$ 以下にも関わらず, 直接打錠可能な流動性に優れる粒子であった。この SDCoP の圧縮成形性を Fell らが提唱した錠剂引張強 度を用いて比較したところ，SDCoP の錠剤引張強度 は, 市販の直接打錠用乳糖以上であり，良好な圧縮 成形性を示した。アセトアミノフェン含有マトリッ クス錠剂を用いて SDCoPの徐放化機能を検証した。 SDCoP を用いた錠剂はゲル形成能を持つ NaAlgの 含量が少量であるにも関わらず，日本薬局方第 1 液 （pH1.2）では NaAlg 原末をマトリックス錠剂用基剂 として用いたときとほぼ同等な薬物放出挙動を示し, 充分な薬物放出制御能を有した。又, SDCoP の徐放 性基剂としての薬物放出制御能は, 基剂中の $\mathrm{NaAlg}$ 


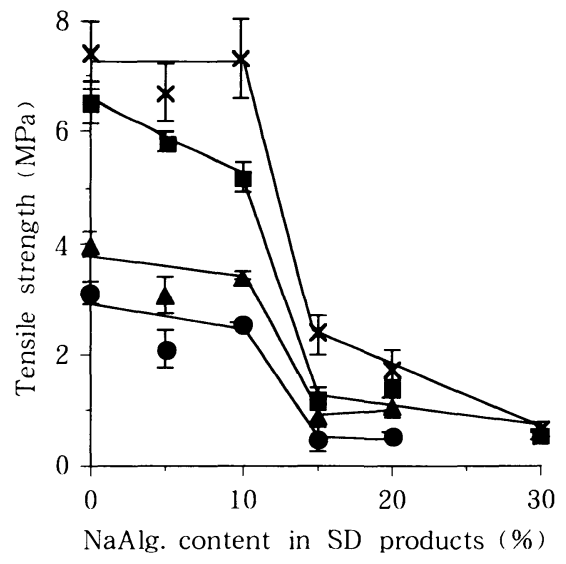

Fig. 1 Effect of NaAlg content in SDCoP on the tensile strength of tablet at compression pressure : (O) $150 \mathrm{MPa}$,
(ム) $200 \mathrm{MPa}$,
$300 \mathrm{MPa}$ and (x) $400 \mathrm{MPa}$

含有の増加に伴い増大したが, 压縮成形性は低下し た（Fig. 1)。その原因は，SDCoP 中の非晶質乳糖の ガラス転移温度が NaAlg 添加割合と共に増大し, 圧 縮成形時の粒子の压縮成形性に影響を及ぼすことと, SDCoP 中の NaAlg 含量が $10 \%$ 以上になるとパーコ レーション現象が起き, 粒子表面に形成された良好な 融合・合一性を示す非晶質乳糖の連続相が不連続とな ることを明らかにした。

以上の結果から，本基剤への機能性の付与には，非 晶質化した乳糖が大きく関与することが判った。し かし, 非晶質乳糖は熱力学的に不安定であり, 安定 な結晶体に容易に転移することが知られている。本 複合粒子では, 粒子中の非晶質乳糖は NaAlg の存在 により結晶化が抑制されることが判明した。SDCoP 中の非晶質乳糖部位のガラス転移温度が, GordonTaylor の式で予測された值よりも增大したことか ら, NaAlg は乳糖之相互作用し, 本複合粒子の安定 性を向上させていることが示唆された（Fig. 2)。

\section{2 噴霧乾燥複合粒子を用いた放出時間制御型錠} 剂の設計

$\mathrm{pH}$ 感受性水溶性高分子である NaAlg の特徵を噴 霧乾燥処理で充分に引き出すことができた。すなわ ち，SDCoPを用いたマトリックス錠剤は，酸性では 徐放性を中性では速やかな薬物放出を示し, その程度 は, NaAlg 含有錠剂の薬物放出と比較して大きいこ

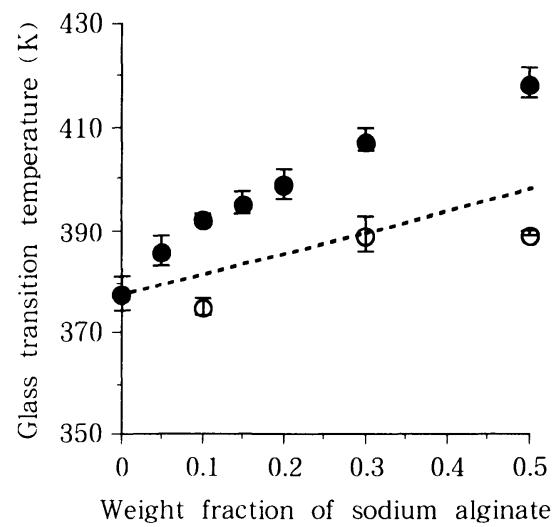

Fig. 2 Effect of NaAlg contents on the glass transition temperature of (O) SDCoP. ( $\bigcirc)$ physical mixtures of amorphous lactose and NaAlg.

The line represent the theoretical line predicted by Gordon-Taylor equation

とが明らかとなった。そこで, SDCoP を外層基剂と した有核錠の設計を企図した。その薬物放出性を検討 したところ，局方第 1 液では薬物放出が認められず耐 酸性を示し, 局方第 2 液では溶出初期に薬物放出が認 められない時間（ラグタイム）を持った放出開始時間 制御型製剂が設計できることが判った。又，本ラグタ イムは, 有核錠外層の溶解・浸食速度により決定され ることを明らかにした。更に, 噴霧乾燥処理時にアル ギン酸ナトリウムを極少量のキオサンで改質すること で大腸ターゲッティングが可能なラグタイムが得られ ることを明らかにした。又, 有核錠の圧縮性成形性支 配因子を検討し，圧縮成形性に優れた本複合粒子は， 有核錠外層基剂としても適していることを明らかに出 来た。

\section{4. おわりに}

本研究に際し, 終始御懇篤なる御指導御鞭撻を賜り ました恩師岐皁薬科大学川島嘉明教授に深甚なる謝意 を表します。又, 本研究の遂行にあたり御指導と御鞭 撻を賜りました岐阜薬科大学竹内洋文助教授, 山本浩 充助手, 徳島大学薬学部日野知証助教授, ファイザー 製薬丹羽敏幸博士，並びに同研究室出身者各位に深く 感謝の意を表します。

(学位取得は 2000 年 2 月, 岐皁薬科大学) 